\title{
Perception of Palm Sugar SMEs on E-Commerce in Business Development Effort
}

\author{
*Agus David Ramdansyah \\ Economics and Business Faculty, \\ University of Sultan Ageng Tirtayasa \\ Jl. Raya Jakarta KM 4, Serang, Banten 42124 \\ *agus.david@untirta.ac.id
}

\author{
Nurul Ummi \\ Engineering Faculty, \\ University of Sultan Ageng Tirtayasa \\ Jl. Jendral Soedirman KM.3 Cilegon, Banten 42435. \\ ft@untirta.ac.id.
}

\author{
Mira Maulani Utami \\ Economics and Business Faculty, \\ University of Sultan Ageng Tirtayasa \\ Jl. Raya Jakarta KM 4, Serang, Banten 42124 \\ feb@untirta.ac.id
}

According to [3] Sila (2013), B2B EC can be

\begin{abstract}
By using descriptive analysis, the purpose of this study is to describe perception of palm sugar SMEs to ability of e- commerce as a media that can help develop their business. Result of this study shows that although use of e- commerce is still low, palm sugar SMEs have perceived benefit of it and can become an opportunity for its implementation in the future. At least this is evidence from the results of an empirical study of 40 palm sugar SMEs in Lebak district. This means that e-commerce can be used as a media to disseminate palm sugar SME products in Lebak District. Implication of this study is that various constraints, regarding length of access time, high cost of access and difficulty of switching from conventional to technology-based, must be overcome by optimizing the use of all features in e-commerce.
\end{abstract}

Keywords: e-commerce, SMEs Palm Sugar, Lebak district

\section{INTRODUCTION}

In the last two decades, technological advances have prompted business to do new business model. As part of it, Internet has dramatically reshaped markets and businesses. Consumers around the world are exposed to new ways of life and consumption and want lots of things they see. [1] state that Managers should support their efforts for growth and profit maximization along with e-commerce adoption and implementation

E-Commerce or Electronics Commerce business models can generally categorized as shown in table I. [2]

TABLE I.

DIFFERENT MODELS OF E-COMMERCE

\begin{tabular}{|l|c|c|c|}
\hline & C (Consumer) & B (Business) & G (Government) \\
\hline C (Consumer) & C2C & C2B & C2G \\
\hline B (Business) & B2C & B2B & B2G \\
\hline G (Government) & G2C & G2B & G2G \\
\hline
\end{tabular}

Source: B.C. Shia et.al (2014) categorized as "outside-in" resources (i.e., those resources used to manage external relationships and related to market responsiveness). While $\mathrm{B} 2 \mathrm{C}$ commercial practice is "any act, omission, course of conduct or representation, commercial communication including advertising and marketing, by a trader, directly connected with the promotion, sale or supply of a product to consumers [4].

$\mathrm{C} 2 \mathrm{C}$ e-commerce opens the realm to developing new relationships and forming new interactions. These interactions do not have to occur through the traditional online $\mathrm{C} 2 \mathrm{C}$ auctions, but can occur in other settings such as discussion forums and chat rooms, with some of those interactions ultimately leading to transactions, [5]. In Consumer - to - Business (C2B) model, individuals use Internet to sell certain products or services to organizations or businesses, [6].

Furthermore, [2] add that there are several other internet business models that refer to electronic commerce. Business to business to consumer (B2B2C). It is Electronic commerce model where business supplies. Business - to Government (B2G). B2G model is a variant of B2B model. Such websites are used by government to trade and exchange information with various business organizations. Such websites are accredited by the government and provide a media to businesses to submit application forms to the government. Government - to - Business (G2B), Government uses G2B model website to approach business organizations. Such websites support auctions, tenders and application submission functionalities. Government - to - Citizen (G2C) Government uses G2C model website to approach citizen as its customers in general. Such websites support auctions of vehicles, machinery or any other material. Such website also provides services like registration for birth, marriage or death certificates. Main objectives of $\mathrm{G} 2 \mathrm{C}$ website are to reduce average time for fulfilling people requests for various government services.

For SMEs the use of e-commerce is an opportunity to reach a broad market even globally with a one-to-one marketing strategy. This is of course offset by the great benefits that can be gained by using e-commerce for palm sugar SMEs. Today the biggest trend of internet use is still dominated by large companies. However, actually the use of e-commerce can also be done by Small and Medium 
Enterprises (SMEs). Some of the palm sugar SMEs in Lebak district have used e-commerce to market their products. Some use social media, but some have already used web applications as e catalogs of products marketed.

This article present the results of an empirical study of 40 palm sugar SMEs in Lebak district regarding their responses to the use of e-commerce in running business. The empirical study uses research variables e-commerce adoption process for product marketing, perception of benefits and constraints.

\section{LITERATURE}

\section{A. Small and Medium Enterprises}

According to [7] concerning SMEs are defined as businesses that have net assets of less than Rp.50 million and less than Rp.300 million for total sales per year. While small businesses are businesses that have net assets of between Rp. 50 million to Rp. 500 million or have total sales per year between Rp. 300 million to Rp. 2.5 billion. Medium Enterprises are businesses that have net assets of Rp. 500 million to Rp. 10 billion or total sales per year from Rp. 2.5 billion to Rp. 50 billion.

[8] noted that In Indonesia there are approximately 57 million SMEs with the absorption of a total workforce of around 108 million people. [9] reports that SMEs also have a central role, in the Asian region, SMEs control an average of 96 percent of the total number of companies with a growth rate of 5 percent each year. [10] list the advantages of ecommerce are convenience, Time saving, Options, Easy to compare, Easy to find reviews, Coupons and deals, Increasing customer base, Rise in sales, 24/7, 365 days, Expand business, Recurring payments made easy, Instant transactions.

However There are many big problems and challenged on the way of an online merchant. Factors like safety and security of online money transaction being the biggest problem along with others have curbed the smooth expansion of the online industry in the country.

\section{B. E-Commerce}

Information technology advances have been able to creating a global network called internet. Today's internet use has also developed in various aspects of life. The use of the internet for various business activities is called E-Commerce. Business activities carried out online can include marketing, promotion, public relations, transactions, payments, and goods delivery scheduling, as well as the possibility of innovations in online business activities along with the development of e-commerce technology itself.

Various applications are developed from 3 (three) basic application categories, which are; 1) Discovery, is an application to access information (browsing and information retrieval / searching), 2) Communication, e-mail, chat, newsgroup and 3) Collaboration, is an application for collaboration between individuals / groups, such as workflow systems, screen sharing, visual teleconferencing, group decision support systems (GDSS).
In addition, [11] state that through applications of ecommerce technologies can benefit from lower transaction costs; reduced staffing requirements; shorter procurement cycles; decreased inventory levels; higher degree of transparency; provision of information on demand which promotes more frequent and intense use of it; connection to operations across organizational boundaries; enlargement of the span of effective control and co-ordination; improvement in the quality of decision-making processes; and enhanced communication and collaboration between supply chain members/organizations.

Furthermore, [12] shows that increased awareness of company's objectives and more user friendly, cost-reduced, standardized and integrated e-commerce systems, together with a positive organizational culture on top management supporting continuous IT training and learning and knowledge-sharing are needed in order to promote better use of e-commerce technologies.

Therefore, e-commerce is a media that can help SMEs improve performance as indicated by [13], [14], and [15] in their study concludes that improvement in enterprise performance and efficiency is the main reason for B2B adoption in the SME sector.

\section{E-Commerce Adoption Process}

[16] state that Innovation refers to improving products, services and the existing processes. Innovation is all goods, services, or ideas that are seen by someone as new. The emergence of various E-Commerce applications then MCommerce is an innovation in the field of information technology.

Innovation can be accepted and used through an adoption process. Adoption process focuses on mental processes that individuals go through from first hearing about innovation to final adoption. Adopters have been conserved moving through five stages [17]: Awareness / awareness: the user is aware of innovation but lacks information about it

a) Interest / interest: the user is stimulated to find information about innovation

a) Evaluation / evaluation: user considers whether to try innovation

b) Trial / trial: the user tries innovation to increase his estimation of value

c) Adoption / adoption: the user decides to use the innovation fully and regularly.

\section{RESEARCH METHODS}

\section{A. Samples}

Samples in this study are palm sugar SMEs in Lebak district, Banten. This study uses quota sampling, which take a sample of 40 units of SMEs. Sampling technique used was purposive sampling.

\section{B. Data Collection Method}

Method to collect Primary data used are:

1) Questionnaire 
It is used to obtain data about e-commerce adoption process, perceptions of benefits and constraints.

2) In-depth interview

This method is conducted to identify more deeply related to indicators of the research variables used.

\section{Data Analysis Methods}

To answer the problems formulated in this study, it was carried out descriptive analysis which includes the following steps:

1) Average score for:

a) E-commerce adoption process:

i. Less than 1.85: don't know

ii. 1.85 - 2.67: awareness

iii. 2.68 - 3.50: interest

iv. 3,51-4,33: evaluation

v. $4,34-5,16$ : trial

vi. 5.17 - 6.00: adoption

b. Interpretation of benefits
i. 4.20 - 5.00: very high
ii. $3,40-4,19$ : high
iii. 2.60 - 3.39: medium
iv. $1,80-2,59$ : low
v. less than 1.80: very low
vi. getting closer to the average score of 5.00, the higher the benefits

c. Interpretation of obstacles

i. $4.20-5.00$ : very high

ii. $3,40-4,19$ : high

iii. 2.60 - 3.39: medium

iv. $1,80-2,59$ : low

v. less than 1.80: very low

vi. the closer to the average score of 5.00, the higher the obstacle

\section{Descriptive qualitative}

\section{RESULTS AND DISCUSSION}

\section{A. E-Commerce Adoption Process of palm sugar SMEs in Lebak district}

E-commerce adoption process of palm sugar SMEs is shown in table II.

TABLE II

E-COMMERCE ADOPTION PROCESS OF PALM SUGAR SMES IN LEBAK DISTRICT

\begin{tabular}{|l|c|c|}
\hline \multicolumn{1}{|c|}{ E-commerce services } & $\begin{array}{c}\text { Average } \\
\text { score }\end{array}$ & Interpretation \\
\hline $\begin{array}{l}\text { Communication and interaction (chat } \\
\text { and e-mail) }\end{array}$ & 2,33 & Awareness \\
\hline $\begin{array}{l}\text { Access data and information (news, } \\
\text { product information, prices, product } \\
\text { attributes, etc.) }\end{array}$ & 1,65 & Do not know \\
\hline $\begin{array}{l}\text { Transactions (banking, shopping and } \\
\text { reservations) }\end{array}$ & 2,48 & Awareness \\
\hline $\begin{array}{l}\text { Remote control and decision } \\
\text { Making (automatic application) }\end{array}$ & 1,45 & Do not know \\
\hline
\end{tabular}

\begin{tabular}{|l|c|c|}
\hline $\begin{array}{l}\text { Other Applications \& Services } \\
\text { (searching, browsing, tracking) }\end{array}$ & 1,67 & Do not know \\
\hline Average total score & 1,92 & Awareness \\
\hline
\end{tabular}

Source: Primary data processed (2018)

In general, from 5 kinds of services in e-commerce, adoption process of SME is relatively low. Total score for adoption process of SMES is 1, 92. It shows that that they have already known about fifth of e-commerce service, but the information still very a little (level awareness). This certain could influence something circumstances in where an innovation could be accepted and used by the user as well aim innovation that created, through a process adoption.

SMEs still do not know about the ability of ecommerce services to access information and data, remote control and decision making, as well as other applications and services. This matter means they do not know about ability ecommerce services as a media for identify situations, problems, and related to far distance decision making without having to meet physically with the involved parties.

\section{B. Palm sugar SMEs perception of e-commerce benefits}

Palm sugar SMEs perceive that the application of ecommerce to support company's operating system is quite useful from marketing, inventory, manufacturing process and materials procurement. The average total score is 3.48 for 8 types of benefits as presented in the table III. It shows that their perception about the eight benefits they can feel and positively responded to efforts to maintain survival even develops their business.

TABLE III

PALM SUGAR SMES PERCEPTION OF E-COMMERCE BENEFITS

\begin{tabular}{|c|c|c|}
\hline Benefits Type & $\begin{array}{l}\text { Average } \\
\text { Score }\end{array}$ & Interpretation \\
\hline $\begin{array}{l}\text { Allows organizations to reach large } \\
\text { numbers of potential customers, } \\
\text { anywhere in the world, with relatively } \\
\text { inexpensive investment and operating } \\
\text { costs }\end{array}$ & 3,65 & High \\
\hline $\begin{array}{l}\text { Procurement of goods can be done } \\
\text { electronically with suppliers around the } \\
\text { world with fast time and costs } 15 \% \text { to } \\
30 \% \text { cheaper than procurement in other } \\
\text { ways. }\end{array}$ & 2,80 & Medium \\
\hline $\begin{array}{l}\text { Distribution channel can be eliminated, } \\
\text { thus the price of the product can be } \\
\text { cheaper and get higher profit. }\end{array}$ & 3,70 & High \\
\hline $\begin{array}{l}\text { E-commerce reduces the cost of } \\
\text { making, entities, distribution, storage, } \\
\text { and information retrieval compared to } \\
\text { the use of documents }\end{array}$ & 3,08 & Medium \\
\hline $\begin{array}{l}\text { E-commerce allows a reduction in the } \\
\text { amount of inventory that must be stored } \\
\text { (Just In Time Inventory and } \\
\text { Production). }\end{array}$ & 3,60 & High \\
\hline $\begin{array}{l}\text { Customer relationship is enhanced by } \\
\text { interactive facilities and one-to-one } \\
\text { marketing. }\end{array}$ & 3,55 & High \\
\hline $\begin{array}{l}\text { E-commerce reduces } \\
\text { telecommunication costs }\end{array}$ & 3,42 & High \\
\hline $\begin{array}{l}\text { Advertising can be done with rich } \\
\text { media, easily changed, reach a broader, } \\
\text { customizable. }\end{array}$ & 4,02 & High \\
\hline Average total score & 3,48 & High \\
\hline
\end{tabular}

Source: Primary data processed (2018) 


\section{Perception of E-commerce Application Constraints}

Although the application of e-commerce can support the development of product marketing SMEs, but the implementation does not always work smoothly and users can find five kinds of obstacles as presented in table 3 which based on the perception of SME palm sugar SMEs:

TABLE IV

PERCEPTION OF E-COMMERCE APPLICATION CONSTRAINTS

\begin{tabular}{|l|c|c|}
\hline \multicolumn{1}{|c|}{ Types of Constraints } & Average & Interpretation \\
\hline Internet access takes a long time & 3,90 & High \\
\hline $\begin{array}{l}\text { E-commerce access fees are relatively } \\
\text { expensive for me }\end{array}$ & 3,55 & High \\
\hline $\begin{array}{l}\text { E-commerce access costs are relatively } \\
\text { expensive when compared to the } \\
\text { benefits that I can get. }\end{array}$ & 2,92 & Medium \\
\hline $\begin{array}{l}\text { It is difficult to switch to technology- } \\
\text { based ways to shop / get products. }\end{array}$ & 4,10 & High \\
\hline $\begin{array}{l}\text { My company still prefers to transact in } \\
\text { the usual way (using documents and } \\
\text { meeting directly between buyers and } \\
\text { sellers). }\end{array}$ & 4,08 & High \\
\hline Average total score & 3,71 & \\
\hline
\end{tabular}

Source: Primary data processed (2018)

Based on the table IV, there is a fairly high perception of the five types of constraints in the application of ecommerce (average total score of 3.71). Although they have a fairly good perception of the benefits of e-commerce, the constraints are still high. Palm sugar SMEs perceive highlevel constraints as being in their difficulties to switch to technology-based ways to shop and transactions that are still done in a physical way.

To open up opportunities for e-commerce applications so that SME products can be marketed more broadly and without limits, the constraints it must be overcome. The response of SME entrepreneurs regarding their desire to get a broader market with more varied, efficient promotional media, trimming the distribution chain from suppliers and buyers, and keeping production quantities adjusted to market demand. Of all these desires, it seems that e-commerce applications are expected to facilitate optimal benefits.

\section{CONCLUSION}

Based on discussion, it can be concluded that the opportunity to develop palm sugar SMEs in Lebak district by using e-commerce is quite high. This means that palm sugar SMEs can optimize e-commerce a media to disseminate their products. Thus the development of palm sugar SMEs product can be achieved with its ability to reach a wider market. As for transactions, it is still done physically in the sense that there needs to be a meeting between consumers (market) and palm sugar SMEs as well as distributors. These opportunities are shown by the following findings:

a) Use of e-mail in e-commerce application features by palm sugar SMEs b) The desire of palm sugar SMEs to reach a wider market with innovative ways based on efficient technology.

\section{SUGGESTIONS}

Various constraints perceived by Palm sugar SMEs, regarding to length of access time, high cost of access, difficulty of switching to technology-based ways to shop and conventional transactions, must be overcome by optimizing the use of all features in e-commerce. This socialization can be carried out by either central government or the local government which concern and fosters the existence of palm sugar SMEs and become a coordinator and responsible party in implementing e-commerce as a media to develop them.

In further research, it is necessary to study in more detail related to cost benefit analysis, so that it can provide stronger evidence that developing palm sugar SMEs with ecommerce facilities is more efficient and practical.

\section{REFERENCES}

[1] Dimitrios Maditinos, Dimitrios Chatzoudes and Lazaros Sarigiannidis, (2014),"Factors affecting ebusiness successful implementation", International Journal of Commerce and Management, Vol. 24 Iss 4 pp. 300320

[2] Ben Chang Shia, Agus David Ramdansyah and Shuyan Wan, Proceedings of the $19^{\text {th }}$ International Conference on Information Quality (ICIQ-2014

[3] Ismail Sila, Factors affecting the adoption of B2B ecommerce technologies, Electron Commer Res (2013). 13:199-236, DOI 10.1007/s10660-013-9110-7,P-203.

[4] Monika Namyslowska, To B2C or Not to B2C. Some Reflections on the Regulation of Unfair Commercial Practices from a Polish Perspective, J Consum Policy (2013) 36:329-342 DOI 10.1007/s10603-013-9229-x, P-331.

[5] Lori N. K. Leonard, Attitude Influencers In C2c ECommerce: Buying And Selling, Journal Of Computer Information Systems, Spring 2012, p-11.

[6] Prof. Mirjana Sekulovska, Ph.D., Internet Business Models for E-Insurance and Conditions in Republic Of Macedonia, Procedia - Social and Behavioral Sciences 44 (2012) 163 - 168, P. 164.

[7] Republic of Indonesia Law No. 20 of 2008

[8] Indonesian Statistics Center. 2014. Table of developments in SMEs in the 1997-2012 period.

[9] Asian Development Bank Institute. 2016. Major challenges facing small medium-sized enterprises in Asia and solutions for mitigating them. ADBI Working Paper.

[10] Dr. C. Eugine Franco, Bulomine Regi. S. Vol.4 (Iss.3: SE): March, 2016] ISSN- 2350-0530(O) ISSN- 23943629(P). International Journal of Research GRANTHAALAYAH

[11] Davila A., Gupta M. and Palmer R. (2003). Moving procurement systems to the Internet: The adoption and 
use of e-procurement technology models, European management Journal, Vol. 21, No. 1, 11-23.

[12] Patrick X.W. Zou, Dr. and Youngsin Seo, Effective Applications of E-Commerce Technologies in Construction Supply Chain: Current Practice and Future Improvement, Journal of Information Technology in Construction (ITcon), ITcon Vol. 11(2006), pg. 127.

[13] Elizabeth Daniel, Hugh Wilson, (2002) "Adoption intentions and benefits realized: a study of e-commerce in UK SMEs", Journal of Small Business and Enterprise Development, Vol. 9 Issue: 4, pp.331 348, https://doi.org/10.1108/14626000210450522
[14] Davies, A. J. (2003). Disparities between B2B and B2C Commerce for SMEs. Bled e-commerce conference: e-transformation. Slovenia. Bled.

[15] Ifinedo, P. (2005). The determinants of extent of internet / e-business technologies use.

[16] Dorothy Leonard and Jeffrey F. Rayport (1997), Spark Innovation Through Emphatic Design, Harvard Business Review.

[17] Kotler, Philip. "Marketing Management". International Edition. 11th Edition. Upper Saddle River, NJ: Prentice Hall, 2003. 